\title{
Notes
}

\section{Medical Malpractice Law and \\ Health Care Cost Containment: \\ Lessons for Reformers from the \\ Clash of Cultures}

\author{
Jonathan J. Frankel
}

The American public finally seems ready for comprehensive reform of its health care delivery system, having been spooked, in part, by the prospect of two impending crises. The first is a crisis of costs: medical expenditures are consuming a frighteningly large (and ever-larger) portion of the nation's resources. In 1993, Americans spent roughly $\$ 3900$ per person on health care for a total of $\$ 942.5$ billion. ${ }^{1}$ Over the past forty years, spending for health care has grown 3\% faster than expenditures for all other goods and services; such spending now accounts for $13 \%$ of all consumption in the U.S. economy. If the current rate of growth continues, health care expenditures will consume almost a third of GNP by the year $2030 .^{2}$

1. INTERNATIONAL TRADE ADMIN., U.S. DEP'T OF COMMERCE, U.S. INDUSTRIAL OUTLOOK 1994, at 42-2 (1994).

2. Victor R. Fuchs, No Pain, No Gain, 269 JAMA 631, 631 (1993). By comparison, most industrialized countries spend 6-9\% of their GDP on health care. HENRY J. AARON, SERIOUS AND UNSTABLE CONDITION: FINANCING AMERICA'S HEALTH CARE 80 (1991).

There is nothing inherently wrong with such a high level of expenditures or such a fast rate of growth, given that the increasing costs of medicine in large part reflect its increasing technological capabilities. See, e.g., Joseph P. Newhouse, An Iconoclastic View of Health Care Cost Containment, HEALTH AFF., 1993 Supp., at 162-65; William B. Schwartz, The Inevitable Failure of Current Cost- 
The second crisis is the perceived failure of the increasingly burdensome tort system we use to assign liability for medical malpractice and to compensate victims of care-related injuries. The cost of malpractice insurance has skyrocketed over the past twenty years: physicians now pay more than $\$ 5$ billion yearly in insurance premiums, and hospitals spend roughly half again as much. ${ }^{3}$ The indirect costs of malpractice liability are even higher. "Defensive medicine"- tests and procedures provided primarily to minimize the chance of future litigation-may cost the country an additional $\$ 15$ billion each year. ${ }^{4}$ In certain medical specialties and geographic areas disproportionately burdened by insurance costs, shortages have developed where physicians have stopped performing services because of liability concerns. ${ }^{5}$ Furthermore, most critics agree that despite these heavy costs, the current system of tort liability does a terrible job of compensating the victims of negligent injuries: only a small fraction of injury claims are pressed and an even smaller fraction compensated, compensation is often unrelated to the existence of actual medical negligence, the system rewards bluffing and intransigence rather than speedy resolution of claims, and legal fees and administrative costs eat up almost half the resources available for compensation. $^{6}$

Containment Strategies: Why They Can Provide Only Temporary Relief, 257 JAMA 220, 220-21 (1987). The crisis comes from our unwillingness (or inability) as a society to continue paying what we have in the past for these advances, coupled with our perception that our expenditures are not purchasing quality care or guaranteeing access to care as effectively as they could be.

3. Robert Pear, Clinton May Seek Lid on Doctor Fees and Liability Suits, N.Y. Times, Mar. 9, 1993, at A1, A14. By comparison, expenditures for malpractice insurance in 1960 totaled $\$ 60$ million, PAUL C. Weiler, Medical Malpractice on Trial 2 (1991).

4. Pear, supra note 3, at A14. The true costs of defensive medicine are notoriously difficult to pin down. The most cited empirical study found that physicians ordered between $\$ 9.1$ billion and $\$ 10.6$ billion in defensive care in 1984 based on surveys of self-reported changes in practice patterns and objective increases in the number of certain procedures performed. Roger A. Reynolds et al., The Cost of Medical Professional Liability, 257 JAMA 2776 (1987). The American Medical Association's \$15 billion figure cited in the text is extrapolated from this study.

Still, these estimates are misleading: they do not include any calculation of the benefits patients have received from more thorough care, better record keeping, or medical injuries avoided. Cf. AARON, supra note 2, at 45-46. Paul Weiler has found this one-sided focus on the costs of defensive medicine puzzling; he asks us to "[c]onsider what our reaction would be to a finding that motor vehicle litigation was inducing widespread defensive driving." WEILER, supra note 3, at 88 . His team's study of medical injuries and malpractice litigation in New York found that hospitals facing the highest risk of lawsuits did have perpatient costs significantly above the state average (presumably because of increased defensive medicine), but they also had significantly lower rates of injury due to physician negligence. Id. at 88-90.

All the same, it is indisputable that physicians perceive that they are prescribing more tests and procedures because of liability concerns, see, e.g., Stanley Joel Reiser, Malpractice, Patient Safety, and the Ethical and Scientific Foundations of Medicine, in THE LIABILITY MAZE 227, 230-32 (Peter W. Huber \& Robert E. Litan eds., 1991). And in any case, as discussed infra, text accompanying note 79, the real culprit is the fee-for-service medical economy which has tolerated these distortions in practice patterns, $c f$. WEILER, supra note 3 , at 87.

5. See, e.g., Deborah Lewis-Idema, Medical Professional Liability and Access to Obstetrical Care: Is There a Crisis?, in 2 INST. OF MEDICINE, MEDICAL PROFESSIONAL LIABILITY AND THE DELIVERY OF OBSTEIRICAL CARE 78 (Victoria P. Rostow \& Roger J. Bulger eds., 1989) (noting that physicians are leaving obstetrical medicine because of high insurance premiums).

6. The Harvard Medical Practice Study found that in New York, one claim was filed for every 7.5 negligently inflicted injuries; half of these resulted in some compensation. Even among the most valuable 
Policymakers hoping to take advantage of the public's readiness for change have introduced legislation combining tort reform with new health care financing and delivery mechanisms intended to encourage cost-saving changes in medical practice. The Clinton Administration's reform proposal, for example, attempts to address both the cost and liability crises: the first by capping insurance premium increases and creating regional insurancepurchasing cooperatives (called "health alliances") with the economic muscle to force competing providers to deliver health care more efficiently; and the second by requiring would-be malpractice litigants to submit their claims to arbitration before going to court, by forcing plaintiffs to obtain independent expert certification that their claims are reasonable and meritorious, by limiting the contingency fees that attorneys can charge their clients, and by preventing patients from recovering twice for their injuries from insurance and the courts. ${ }^{7}$ All but one of the competing reform packages currently proposed in Congress likewise combine some sort of cost containment with tort reform. ${ }^{8}$

But even though cost-containment efforts and malpractice reforms sit sideby-side in the same proposed legislation, there has been no effort to evaluate both in the context of a unified strategy. For the most part, the proposed modifications to the tort system are simply national versions of reforms first adopted by individual states in the late $1970{ }^{\prime}$ s. $^{9}$ The more innovative reform

potential claims (serious injuries to patients under age 70), victims received compensation for just one negligent injury in six. The authors believe that these compensation rates are actually inflated, given the number of "false positives" (that is, recoveries where there was no negligence) in the system. Paul C. Weiler et al., Proposal for Medical Liability Reform, 267 JAMA 2355, 2355-56 (1992) see also AARON, supra note 2, at 46-48; Jeffrey O'Connell, Neo No-Fault: Settling for Economic Losses, in MEDICAL MALPRACTICE SOLUTIONS 91, 91-93 (M. Martin Halley et al. eds., 1989); Laurence R. Tancredi \& Randall R. Bovbjerg, Creating Outcomes-Based Systems for Quality and Malpractice Reform, MILBANK Q., Winter 1992 , at $183,183-85$.

7. Health Security Act, S. 1757, 103d Cong., 1st Sess. (1993).

8. See, e.g., Managed Competition Act of 1993, H.R. 3222, 103d Cong., 1st Sess. (1993) (Bipartisan Group on Health Reform's alternative to Administration proposal) (combining insurance-purchasing cooperatives with varying caps on noneconomic damages, ADR and "certificate of merit" requirements, limits on attorney fees, and abolition of joint and several liability); Health Equity and Access Reform Today Act of 1993, S. 1770, 103d Cong., 1st Sess. (1993) (Senate Republican Task Force's alternative) (combining voluntary insurance-purchasing cooperatives and mandated individual coverage with ADR requirements, caps on noneconomic tort damages, $75 \%$ tax on punitive damages, deducting collateral-source recoveries, limits on attorney fees, sanctions for frivolous lawsuits, uniform statute of limitations, abolition of joint and several liability, and physician immunity for following state practice guidelines); Affordable Health Care Now Act of 1993, H.R. 3080, 103d Cong., 1st Sess. (1993) (House Republican alternative) (combining standard benefit packages, insurance reform, and Medicare and Medicaid reform with caps on noneconomic tort damages, higher legal standards for awarding punitive damages, limits on attorneys' fees, uniform statute of limitations, mandatory alternative dispute resolution with penalties for appealing ADR settlement, and abolition of joint and several liability). The exception is the House single-payor bill, the American Health Security Act of 1993, H.R. 1200, 103d Cong., Ist Sess. (1993), which does not contain any tort-reform measures.

9. Cf. Frank A. Sloan, State Responses to the Malpractice Insurance "Crisis" of the 1970s: An Empirical Assessment, 9 J. HEALTH POL., POL'Y \& L. 629, 633-37 (1985). The currently proposed menu of reforms-caps on damage awards, limits on attomey fees, and modification of the collateral-source rule-does not differ much from that adopted twenty years ago by California as part of its Medical Injury Compensation Recovery Act (MICRA), ch. 1, 1975 Cal. Stat. 3949. Cf. Brian McCormick, Enterprise Liability Backers Stand Firm, AM. MED. NEws, June 21, 1993, at 1, 25 (describing AMA negotiations with 
proposals-such as the Administration's extremely short-lived plan for enterprise liability ${ }^{10}$ and the conservatives' proposals for the abolition of joint and several malpractice liability ${ }^{11}$ - have responded far more to their drafters' need to negotiate interest-group support than to the dramatic changes in the institutional structure of American health care brought about by the last decade's crisis in medical costs. If anything, the political abandonment of enterprise liability and embrace of the abolition of joint and several liability reflect a resistance to (or at least a disregard for) those very changes. ${ }^{12}$

In short, the debates over reforming liability law and controlling medical costs have taken place simultaneously but in isolation from one another. That both topics may soon be addressed is more a function of the current political moment than of any careful consideration of whether these issues might be linked. This Note takes the position that by failing to consider how health care cost-containment measures might interact with the tort system, policymakers put their reform efforts in serious jeopardy.

That cost containment and tort reform are connected becomes apparent when we compare the preconditions for effective cost control to the demands of malpractice law. Although politicians and optimistic reformers like to talk about saving money through the simple elimination of "unnecessary" or "useless" medical care ${ }^{13}$ most observers realize that this idea is naive. The

Clinton Administration to work national versions of MICRA reforms into final legislation).

10. The Clinton Administration had initially proposed a system by which individual health care providers would be immune from malpractice lawsuits. Injured patients would instead sue the health plans to which the providers belonged. See, e.g., Mark Crane, The Malpractice-Reform Idea that Won't Go Away, MED. ECON., July 26, 1993, at 27; Sara Fritz \& David Savage, Health Reform Plan May Exempt Doctors from Suits, L.A. TIMES, May 5, 1993, at Al. Enterprise liability is an intuitive response to the newly changed structure of health care delivery, in which causal responsibility for medical decisionmaking has become diffuse; the concept is discussed in greater detail infra Part III.B.2.

11. E.g., H.R. 3222, § 5104(c) (Bipartisan Group on Health Reform's alternative); S. 1770, $\$ 4024$ (b) (Senate Republican alternative); H.R. 3080, \$ 2014 (House Republican alternative). These proposals would require the finder of fact to partition responsibility for medical injuries among the various defendants and to set damages in proportion to their degrees of responsibility. Plaintiffs would no longer be able to recover the full amount of damages from any single defendant.

12. The Administration downgraded the enterprise liability plan to a demonstration project once its intended beneficiaries, the physicians who would be immune from suit, surprised the drafters with intense opposition. The American Medical Association and other provider groups believed enterprise liability would ratify and accelerate their loss of professional autonomy by formally ceding responsibility for overseeing medical quality to the health plans; in addition, the physician-owned liability insurance companies stood to lose most of their market. See, e.g., McCormick, supra note 9, at 1; Brian McCormick, Enterprise Liability Out, AM. MED. NEws, June 28, 1993, at 1; David Rogers, Initial Clinton Medical Malpractice Reform Plan Pulled After Resistance by Entrenched Interests, WALL ST. J., June 15, 1993, at A20. This quick about-face suggests that the Administration had considered enterprise liability more as a way to encourage physician support for the reform package as a whole than as a response to the blurred chains of responsibility for medical decisionmaking found in the new cost-conscious medical practice context.

Similarly, the Republicans' and conservative Democrats' retreat from joint and several liability is wholly out of step with the recent evolution of health care delivery. What defines the new practice culture is that the partitioning of responsibility has become incredibly difficult, given the increasing influence of lay entities (such as third-party payors) on the process of medical decisionmaking. See infra text accompanying notes 83-86.

13. See, e.g., Anold S. Relman, Is Rationing Inevitable?, 322 NEW ENG. J. MED. 1809 (1990) (asserting that the identification and elimination of "useless" care can achieve sufficient cost savings to 
problem is not that physicians are giving patients care that has zero medical benefit; rather, it is that they are prescribing significant amounts of care that yields some positive health benefit to the individual patient but that is not costjustified from society's point of view. Individuals with employer-subsidized or indemnity-plan insurance accept this care because they see the positive medical benefits of the procedures but do not themselves face the full costs. ${ }^{14}$ For health care cost containment to achieve significant and lasting gains, then, it must modify physician practice patterns to eliminate the provision of care that has marginally positive medical benefits but is not in some sense costeffective. ${ }^{15}$

The current proposals for health care reform attempt to adjust current medical practice patterns and cut costs by modifying the economic supports of the status quo- that is, by influencing consumer demand and provider supply. The "managed competition" scheme favored by President Clinton seeks to make consumers more sensitive to the costs of their health care and to give them incentives to seek more efficient delivery of services from suppliers. Advocates of the program envision that integrated managed-care organizations (such as HMO's) will be the eventual winners in the competition among health plans for the cooperatives' customers. ${ }^{16}$ They point to the success that managed-care groups have had in encouraging cost-conscious behavior among physicians. Such groups use utilization controls that review the treating physicians' prescribed courses of care and compensation arrangements that shift the financial risks of high-cost care to the providers. ${ }^{17}$

avert crisis); cf. James F. Blumstein et al., Report of the Panel on Cost Containment, in INST. FOR CIVIL JUSTICE, HEALTH CARE DELIVERY AND TORT: SYSTEMS ON A COLLISION COURSE? 76, 82 (Elizabeth Rolph ed., 1992) (noting political actors' tendency to overemphasize the cost savings possible from eliminating "unnecessary" care because of its obvious win/win characteristics).

14. See, e.g., AARON, supra note 2, at 8-23.

15. See, e.g., Fuchs, supra note 2, at 631-32 (stressing need to eliminate "low-yield" health care, not just "unnecessary" care); Schwartz, supra note 2, at 222-24 (arguing that lasting cost containment requires restrictions on marginally beneficial care and willingness to forego some degree of technological advancement).

I hedge on the term "cost-effective" because it connotes an objectivity that does not exist. What care is deemed "cost-justified" or "appropriate" is always the function of a social judgment of what claims on medical resources a patient is entitled to make. See discussion infra text accompanying note 89.

16. E.g., Alain C. Enthoven, The History and Principles of Managed Competition, HEALTH AFF., 1993 Supp., at 24, 37-39. For a good overview of current managed-care techniques, see U.S. GEN. ACCOUNTING OFFICE, Pub. No. HRD-94-3, MANAGEd HeAlTH CARE: EFFECT ON EMPloyers' Costs Difficult to MEASURE 4-10 (1993).

17. See, e.g., Alan L. Hillman et al., How Do Financial Incentives Affect Physicians' Clinical Decisions and the Financial Performance of Health Maintenance Organizations?, 321 NEW ENG. J. MED. 86 (1989) (finding use of capitated payment or salaries associated with significantly lower rate of hospital utilization than use of fee-for-service physician reimbursement); Willard G. Manning et al., $A$ Controlled Trial of the Effect of a Prepaid Group Practice on Use of Services, 310 NEw ENG. J. MED. 1505, 1507 (1984) (Rand study finding that HMO enrollees use 40\% fewer hospital days and incur approximately $25 \%$ fewer expenses than matched individuals in fee-for-service plans). Extrapolating from these data, the Congressional Budget Office estimated that if all people currently insured were enrolled in staff- or groupmodel HMO's, health care costs would have been $\$ 78$ billion less in 1992. Verdon S. Staines, Potential Impact of Managed Care on National Health Spending, HEALTH AFF., 1993 Supp., at 248, 253. By comparison, U.S. health care expenditures in 1992 totaled over $\$ 800$ billion. Fuchs, supra note 2, at 631 . 
However, this approach ignores the noneconomic factors responsible for current medical practice patterns. One such factor is the law of medical malpractice. Tort doctrine holds medical providers to a certain standard of care, and the actions and interventions that the law requires are set without regard to cost. Medical malpractice law is built upon a definite cultural conception of health care delivery, one in which physicians have sole authority to define appropriate health care outcomes for society and are obligated to do so without reference to patient (or system) resources. Efforts to contain medical costs by forcing physicians to alter their practices to take account of economic concerns cut directly across the grain of this ideal. Plans for cost containment thus risk direct collision with the tort system.

Part I of this Note gives an idea of how this clash might play itself out. It discusses how courts applying the traditional tort doctrines have dealt with the new realities of cost-conscious medical delivery, using as a case study disputes in which a court (always with great difficulty) has had to assign liability for medical injuries that are more the result of economically motivated controls on health care utilization than of provider negligence. Part II attempts to understand why the courts in these cases have found their task so difficult; to do so, this Part fleshes out the deeper cultural images of medical decisionmaking and professional authority implicit in malpractice doctrine and looks at how these conceptions conflict with the new, cost-conscious practice culture. Based upon these lessons, Part III proposes a solution-framed as a two-step inquiry into medical and quasi-medical negligence-for policymakers and courts seeking both meaningful liability reform and effective cost containment.

\section{LIABILITY FOR INJURIES FROM UTILIZATION CONTROLS: A CASE STUDY}

Currently, about $95 \%$ of all employees covered by health insurance are enrolled in plans that monitor and manage the treating physician's prescription of services. ${ }^{18}$ The goal of such utilization management, according to the Health Insurance Association of America, is to "prospectively and concurrently assess the appropriateness of care and the site in which care is delivered to control costs and improve quality."19 Management techniques include requiring physicians to obtain certification of medical necessity from the plan financer or a contracted review organization before giving treatment,

More recent commentators question the ability of health care consumers to recapture the cost savings from decreased utilization of medical services in the form of decreased insurance premiums. They still agree, however, that utilization-management techniques do in fact encourage changes in physician practice patterns. See, e.g., U.S. GEN. ACCOUNTING OFFICE, supra note 16, at 12-14.

18. Elizabeth W. Hoy et al., Change and Growth in Managed Care, HEALTH AFF., Winter 1991, at $18,19$.

19. Id. at 27. 
demanding second opinions before surgery, performing ongoing reviews of hospital stays, planning discharges, and actively managing the course of treatment in potentially high-cost cases. ${ }^{20}$

Empirical evidence suggests that utilization management techniques do change physician practice patterns. A health plan's use of mandatory precertification and review concurrent with treatment is associated with significantly lower hospital admissions, shorter stays, and lower expenditures. On average, every dollar spent on utilization review saves almost nine in changed patterns of practice. ${ }^{21}$

Health insurers have always reviewed claims for benefits and refused to reimburse care that was not medically necessary. These newer forms of utilization management differ from prior practices in that the determination of whether or not the health plan will pay for the care takes place before medical services are actually provided. Because of this, a review organization's decision as to whether or not to fund treatment and if so in what form inevitably structures the physician's and patient's choice among treatment options, even if the ultimate choice will be made by the physician. This is especially true when the patient's financial constraints effectively turn a denial of third-party funding into a denial of access to care.

Patients have recently begun to bring lawsuits against health plans and utilization review companies for adverse medical outcomes incident to these review determinations. These cases are significant, not only because of the prevalence of utilization review and the financial stakes involved, but also because they illustrate most directly the clashes between the institutional realities of the new cost-conscious medical practice culture and the ideological supports of the old one. The litigants in these cases spar over the extent to which a lay financing entity has appropriated to itself distinctly medical authority by substituting its own expertise for that of the treating physician. At issue is nothing less than the definition of medical decisionmaking itself.

This section examines three such cases. In each, a court has had to decide the extent to which an insurer's cost-containment mechanism could be factually and legally responsible for a treating physician's alleged malpractice. In one case, the plaintiffs were allowed to proceed with the suit against the health plan; in the two others, the cause of action was denied. Together, the three

20. For a more detailed discussion of utilization-review techniques, see U.S. GEN. ACCOUNTING OFFICE, PUB. No. HRD-93-22FS, UTILIZATION REVIEW: INFORMATION ON EXTERNAL REVIEW ORGANIZATIONS 8-9 (1992).

21. Paul J. Feldstein et al., Private Cost Containment: The Effects of Utilization Review Programs on Health Care Use and Expenditures, 318 NEw ENG. J. MED. 1310 (1988). In this survey of claims data from 222 employee groups, review was associated with $12.3 \%$ lower hospital admissions, $8.0 \%$ fewer patient days, $11.9 \%$ lower hospital expenditures, and $8.3 \%$ lower total medical expenses. The reductions in service use were even greater for groups that had been high-users of hospital care before the start of utilization review; for these groups, $\$ 1$ spent on review saved over $\$ 28$ in decreased hospital costs. $I d$. at 1310,1314 . 
opinions yield very few principles of consensus, demonstrating the difficulty of forcing new facts into old doctrinal paradigms.

\section{A. Wickline v. State 22}

Lois Wickline was diagnosed with Leriche's Syndrome, a vascular occlusion. Her doctor recommended surgery to replace part of an artery with a Teflon graft. Wickline received her medical care through Medi-Cal, California's medical assistance program, which controlled costs by requiring prospective and concurrent treatment review. Accordingly, her doctor could only perform the surgery after receiving authorization from the state to proceed.

Medi-Cal soon approved Wickline's surgery and allowed for ten days of recuperative hospital care. Wickline had a difficult recovery after the surgery took place. One day before she was scheduled for discharge, her surgeon and his assistant concluded that an eight-day extension of hospital care would be necessary. As he did for the original surgery, the surgeon applied to the MediCal utilization review consultants for the requisite prior approval of the eight additional days of hospitalization.

This time, however, Medi-Cal disagreed with the surgeon's recommendations. The Medi-Cal consultant, himself a board-certified surgeon, would only approve a four-day extension of hospital care. The consultant made his determination based entirely on information learned from a phone conversation with a Medi-Cal nurse who had first reviewed the case; he did not review any documentary evidence himself, nor did he consult with a vascular-surgery specialist. He later testified that he evaluated the progress of Wickline's recovery on the basis of information he had learned about her temperature, diet, and bowel function.

Upon Medi-Cal's denial of the eight-day extension, the treating surgeon and his assistant wrote a discharge order for Wickline. They did not push for the additional hospital days because they did not feel the patient's condition was deteriorating. In addition, as the treating physician later testified, they believed Medi-Cal had the authority to order the discharge of the patients for whose care it paid; they also believed that Medi-Cal's overwhelming concern with controlling costs made it unlikely that it would reverse its decision had they challenged it.

After returning home, Wickline developed severe problems with the Teflon graft in her leg and showed signs of clotting, circulation loss, and infection. She was readmitted to the emergency room nine days after her discharge, but by this point it was too late to intervene-the leg had to be amputated. Wickline later brought suit against the state of California (but not her treating

22. 228 Cal. Rptr. 661 (Ct. App. 1986). 
doctors), alleging that the Medi-Cal consultant's negligent review decision caused her early discharge from the hospital and that had she not been discharged, the problems with her graft would have been noticed in time to save her leg. ${ }^{23} \mathrm{~A}$ jury agreed with Wickline and awarded her $\$ 500,000 .{ }^{24}$

The appellate court reversed the jury verdict, holding that the facts of the case did not justify holding Medi-Cal liable for medical malpractice. The court began by recognizing that the medical stakes in a prospective utilization review program like Medi-Cal's are much higher than in the traditional process of after-the-fact claims review: whereas "[a] mistaken conclusion about medical necessity following retrospective review will result in the wrongful withholding of payment," an "erroneous decision in a prospective review process ... in practical consequences, results in the withholding of necessary care, potentially leading to a patient's permanent disability or death."25 For this reason, the court would not foreclose all causes of action against third-party payors for medical injuries incident to review:

The patient who requires treatment and who is harmed when care which should have been provided is not provided should recover for the injuries suffered from all those responsible for the deprivation of such care, including, when appropriate, health care payors. Third party payors of health care services can be held legally accountable when medically inappropriate decisions result from defects in the design or implementation of cost containment mechanisms as, for example, when appeals made on a patient's behalf for medical or hospital care are arbitrarily ignored or unreasonably disregarded or overridden. ${ }^{26}$

The court stressed the need to preserve medical integrity in the face of new pressures for cost containment, finding it "essential that cost limitation programs not be permitted to corrupt medical judgment." ${ }^{, 27}$

But Wickline could not recover for her injuries, this broad language notwithstanding. The court constructed its inquiry narrowly, taking the decision to discharge the patient from the hospital as the only act of medical decisionmaking at issue in Wickline's case. According to the medical custom prevailing at the time of that decision, the court found, responsibility for a discharge order rested solely with the treating physician. ${ }^{28}$ By this custom, "Medi-Cal was not a party to that medical decision," it concluded, "and

23. Id. at 661-69.

24. David Azevedo, Courts Let UR Firms off the Hook-and Leave Doctors On, MED. ECON., Jan. 25,1993 , at 30,30 .

25. Wickline, 228 Cal. Rptr. at 663.

26. Id. at $670-71$.

27. Id. at 672 .

28. Id. at 670. 
therefore cannot be held to share in the harm resulting if such decision was negligently made." 29

In addition, the court held that the treating physician had a duty to appeal his patient's case if he felt that Medi-Cal's disapproval of the proposed plan of care was medically unsound. The court scolded the surgeon for his failure to protest Medi-Cal's determination:

There is little doubt that [the treating physician] was intimidated by the Medi-Cal program but he was not paralyzed by [the consultant's] response nor rendered powerless to act appropriately if other action was required under the circumstances. If, in his medical judgment, it was in his patient's best interest that she remain in the acute care hospital setting for an additional four days ... [the treating physician] should have made some effort to keep Wickline there. ${ }^{30}$

Having failed to advocate his patient's interests, the court held, the doctor could not make the payor "the liability scapegoat when the consequences of his own determinative medical decisions [went] sour."31 The correct defendant in this case, therefore, would have been the treating physician, not Medi-Cal.

Wickline represents the first time a court attempted to partition causal and legal responsibility for adverse medical outcomes in the new, cost-conscious practice setting. It failed miserably. By limiting its attention to the actual decision to discharge, the court failed to appreciate the role that the practice context played in structuring that decision. For indigent patients like the plaintiff, public medical assistance programs are usually the only source of funding available for medical care; the court itself recognized that the practical effect of denying coverage to these patients is to deny them care. It is also reasonable for a physician in these cases to believe that the public payor has some authority to direct treatment. Certainly Wickline herself thought it was Medi-Cal, not her physicians, that had foreclosed certain treatment possibilities-after all, she sued the state, not her treating surgeons. By focusing exclusively on the discharge order and relying unthinkingly on who had customary authority to make that decision, the court ignored the plaintiff's primary contention: that the old custom had given way to a new medical practice culture.

This artificially constricted frame of reference insulates the utilizationmanagement decision from review. The court never addressed Wickline's actual tort claim - that the Medi-Cal consultant's prescription of a curtailed hospital stay on the sole basis of telephoned information about the patient's

29. Id. at 671 .

30. Id.

31. Id. 
diet, temperature, and bowel function constituted medical negligence. The court did note that the consultant's determination met the vague procedural guidelines of the Medi-Cal statute and regulations, but it never examined the substance of that determination. ${ }^{32}$ Even the court's intimation that on different facts it could hold a third-party payor liable for injuries incident to utilization management does not seem to envision any attempt to review the payor's actual judgments of medical necessity; liability in the court's hypothetical case would flow not from medical negligence in the review determination, but rather from the payor's behavior in arbitrarily ignoring or overriding the appeals of the treating physician. This is something closer to the traditional insurance tort of bad-faith denial of benefits than it is to medical malpractice. ${ }^{33}$ The court's treatment of utilization review as a mere insurance question does not square with its earlier recognition that the "Medi-Cal Consultant's decision required the exercise of medical judgment [in which he] would utilize the skill, knowledge, training and experience he had acquired in the medical field." ${ }^{34}$ This is not to argue that a utilization review determination is in every sense equivalent to the medical decision of a treating physician, but neither are the two judgments so wholly distinct.

One final aspect of the case deserves mention. The court in Wickline made no attempt to adjust the treating physician's duty of care to compensate for the fact that he was providing services within the resource-strapped and costconscious Medi-Cal system. Indeed, the court emphasized that the California legislature intended for Medi-Cal recipients to receive, to the extent possible, the same type of care as those not on public assistance. ${ }^{35}$ If anything, the court actually expanded the duty of care of physicians operating in costconscious practice systems: it imposed on them new legal obligations to navigate for their patients through the payor's minefield of cost and utilization controls.

\section{B. Wilson v. Blue Cross of Southern California ${ }^{36}$}

In 1983, Howard Wilson, Jr., checked himself into a California hospital for psychiatric treatment. ${ }^{37}$ The attending psychiatrist diagnosed him as suffering from major depression, heroin abuse, and a mixed personality disorder; he recommended a three-to-four-week inpatient stay for monitoring and treatment. During the course of treatment, a nurse and a neurologist at the utilization

32. Id.

33. See Blumstein, supra note 13, at 98; see also infra text accompanying notes 84-88.

34. Wickline, 223 Cal. Rptr. at 670.

35. Id. at 671 (citing CAL. WELF. \& INST. CODE $\$ 14000$ (legislature's statement of goals and purposes for Medi-Cal)).

36. 271 Cal. Rptr. 876 (Ct. App. 1990).

37. The facts of this case are drawn from Azevedo, supra note 24, at 30, 37, and Wilson, 271 Cal. Rptr. at 877-78, 881-82. 
review firm employed by Wilson's insurer twice evaluated Wilson's hospitalization. Both times the firm determined that only eleven days of inpatient care were necessary, and the insurer notified the patient that benefits would cease after that time. Because Wilson and his family did not have the money to continue paying for in-hospital treatment, the psychiatrist discharged the patient to his family's care. On the discharge note, the psychiatrist wrote that Wilson "[d]id well in the program but had to leave early because of pressure from PSRO," referring to the review firm. He told Wilson's parents that the utilization review company had "terminated [Wilson's] stay" and that this was a problem that had occurred on other occasions with other patients.

Twenty days after his discharge, Wilson died in his sleep from either suicide or a drug overdose. His parents brought claims for tortious breach of contract against the insurer and the utilization review company ${ }^{38}$ they also sued for wrongful death, alleging that the defendants' conduct resulted in the premature termination of needed medical treatment. Once again, the treating physician was not sued. The trial court granted summary judgment for the defendants on the basis of Wickline v. State, holding that the psychiatrist's failure to challenge the decision of the utilization review company immunized the defendants from liability.

The same appellate division that had earlier decided Wickline reversed the lower court and allowed the Wilsons to proceed to trial. The court essentially rewrote Wickline in the process. In doing so, it first characterized much of its Wickline opinion as dicta, including the parts about liability for discharge decisions resting solely with the treating physician. ${ }^{39}$ The court then said that the real issue in Wickline had been whether or not the decision to discharge the patient from the hospital was within the bounds of then-prevailing customary practice; because that decision had been within standard medical practices, there could be no liability regardless of which actors were actually responsible for the discharge order. ${ }^{40}$

38. The contract causes of action in this case arose from Blue Cross's practice of pooling the claims of its member plans. Wilson was insured by Blue Cross of Alabama, but because he was hospitalized in California, his claim was processed by Blue Cross of Southem California. Wilson's policy with Blue Cross of Alabama entitled him to an automatic 30 days of psychiatric hospitalization and did not require utilization review; Blue Cross of Southern California, on the other hand, employed concurrent utilization review for all of the claims it processed. Wilson, 271 Cal. Rptr. at 880 .

39. Id. at $879-80$.

40. Id. The court also invented a second ground for the Wickline result, somehow reading the opinion as creating an immunity from liability on grounds of public policy for utilization review performed by public entities. $I d$. at 884 . This author remains somewhat confused. I read Wickline's discussion of the Medi-Cal statute and regulations as being meant to counter an argument that utilization review violated public policy and to demonstrate that the review decision was made in accordance with proper procedure. Nowhere does there seem to be an intention to create a broad immunity from liability for public costcontainment efforts. See Wickline, 228 Cal. Rptr. at 671-72.

Regardless of its actual role in the Wickline decision, the intuition that patients in the financially strapped public health care system might be subject to stricter management of resource use than privately funded patients is important. This Note argues that the standard of care owed to patients is necessarily (and has always been) economically contingent; the question, then, is whether we as a society can preserve a 
Its prior decision thus neutralized, the court then reasoned that responsibility for this plaintiff's injuries should be apportioned as it would be in any other tort case involving multiple co-defendants. In California, it noted, "[an] actor's negligent conduct is a legal cause of harm to another if . . . his [or her] conduct is a substantial factor in bringing about the harm." to the facts at hand, it found that by this test the defendants' termination of benefits could indeed have been a proximate cause of Wilson's death:

The sole reason for the discharge ... was that the decedent had no insurance or money to pay for any further in-patient benefits .... [T]he decedent's treating physician . . . believed that had the decedent completed his planned hospitalization that there was a reasonable medical probability that he would not have committed suicide. The foregoing constitutes sufficient evidence to raise a triable issue of material fact as to whether [the defendants'] conduct was a substantial factor in causing the decedent's death. ${ }^{42}$

The court remanded the case for trial, at which point the utilization review company settled with the Wilsons for an undisclosed amount. In 1992, a jury cleared the insurer of the wrongful-death claim but found the company liable on the claim for tortious breach of contract. The parties then settled to avoid appeal. ${ }^{43}$

Wilson corrected some of the deficiencies in Wickline noted above: it recognized the connection between utilization review decisions and medical outcomes, and it scrapped the rule that made the third-party payors' liability contingent upon the treating physician's success or failure in negotiating the procedures of their cost-containment programs. But the Wilson court, like the Wickline court, avoided defining the payor's legal duty of care. It finessed the question of what constitutes negligence in the performance of utilization review by assuming the existence of a breach of duty and proceeding immediately to the issue of causation. It is unclear from the court's opinion whether the defendants' requisite breach lay in the violation of the terms of the decedent's insurance contract, ${ }^{44}$ some inadequacy in the management of the course of medical treatment, or somewhere else. By so dodging the question of duty, the court escaped having to define the process of utilization review as an insurance matter, a medical determination, or something else.

uniform standard of care at the existing level of entitlements or whether instead we should allow that legal standard to vary with the economic and institutional context in which care is provided. See infra text accompanying notes $77-80,102-10$.

41. Wilson, 271 Cal. Rptr. at 883 (brackets in original) (emphasis added) (quoting RESTATEMENT (SECOND) OF TORTS $\$ 431$ (1965)).

42. Id.

43. Azevedo, supra note 24 , at 42 .

44. See supra note 38. 


\section{Corcoran v. United HealthCare, Inc. ${ }^{45}$}

Florence Corcoran was an employee of South Central Bell Telephone Company and a member of the company's self-insured health plan. ${ }^{46}$ She conceived her second child in early 1989. Because her first pregnancy had been troubled, requiring hospitalization and an emergency cesarean section, her obstetrician admitted her to a hospital during the final weeks of the term for full-time monitoring. Although the health plan had paid for similar end-of-term monitoring for the first pregnancy, it now refused; United HealthCare, Bell's utilization review firm, denied certification for inpatient stay and instead authorized ten hours per day of home nursing care. Thirteen days after Corcoran left the hospital, at a time when the home nurse was absent, the thirty-two-week-old fetus went into distress and died.

Corcoran and her husband brought suit against United for wrongful death and medical malpractice. Because the health plan at issue was a self-funded employee benefit plan governed by the Employee Retirement Income Security Act (ERISA), ${ }^{47}$ the suit was removed to federal court. The district court granted the defendants summary judgment on the grounds that ERISA preempted the plaintiffs' state-law tort claims; it felt that the only matter in dispute in the case was the defendants' adjudication of benefits claims under the plan, a subject at the core of the ERISA protections. ${ }^{48}$

The Fifth Circuit affirmed the district court's dismissal on a similar theory. Its opinion focused on one central issue: How should the court characterize the activity of utilization review? The defendants asserted, as they had below, that United had done nothing but apply previously established eligibility criteria to determine whether or not Corcoran qualified for the plan's benefits. ${ }^{49}$ The plaintiffs, on the other hand, stressed the medical nature of United's determination; in support of their claim, they pointed to language in the utilization review program's brochures that explained that United's staff consisted of trained medical professionals who would suggest treatment

45. 965 F.2d 1321 (5th Cir. 1992), cert. denied, 113 S. Ct. 812 (1993).

46. The facts of this case are drawn from Corcoran, 965 F.2d at 1322-24, and Azevedo, supra note 24 , at $30-32$.

47. 29 U.S.C. $\S \S 1001-1461$ (1988).

48. See Corcoran, 965 F.2d at 1325. A full discussion of ERISA preemption is beyond the scope of this Note. Basically, ERISA § 514(a)-(b), 29 U.S.C. § 1144(a)-(b) (1988), preempts all state laws (common Iaw as well as statutes) "relating to" employee benefit plans covered by ERISA with the exception of certain laws regulating banking, insurance, and securities. The Supreme Court has held that ERISA's preemption provisions are "deliberately expansive" and that the phrase "relate to" should be defined very broadly. Pilot Life Ins. Co. v. Dedeaux, 481 U.S. 41, 45-46 (1987). As a result, even state common-law claims that do not make specific reference to benefit plans may be preempted, e.g., Pilot Life, 481 U.S. at 44-57 (holding that common-law action for tortious breach of contract preempted in context of suit over denial of benefits under disability plan). For a more thorough treatment of ERISA preemption, see MICHAEL J. Canan \& William D. Mitchell, Employee Fringe and Welfare Benefir Plans $\$ 1.7$ (1993).

49. Corcoran, 965 F.2d at 1329-30. 
alternatives and work with the physician to develop an ultimate plan of care. ${ }^{50}$ This definitional question was the core of the matter: the Supreme Court had made it clear that tort and contract actions seeking damages for improper processing of benefits claims were preempted by ERISA, ${ }^{51}$ while other cases suggested that pure medical malpractice actions were not. ${ }^{52}$

The court concluded that both sides were right. It held that United did indeed make medical decisions and give medical advice. Like the Corcorans, the court examined the plan literature explaining the review program and found that United had held itself out as possessing independent medical expertise that it would use to recommend alternative and less expensive courses of care to the patient's treating physician. ${ }^{53}$ It dismissed the disclaimers in United's brochure that said that final medical authority always rested with the patient's doctor; the court instead recognized the practical effects of the pre-procedure review program on a patient's ultimate choice of treatment:

[A] system of prospective decisionmaking influences the beneficiary's choice among treatment options to a far greater degree than does the theoretical risk of disallowance of a claim facing a beneficiary in a retrospective system. Indeed, the perception among insurers that prospective determinations result in lower health care costs is premised on the likelihood that a beneficiary ... will choose the treatment option recommended by the plan in order to avoid risking total or partial disallowance of benefits. When United makes a [review] decision ... it is making a medical recommendation which-because of the financial ramifications-is more likely to be followed. ${ }^{54}$

This is the strongest statement yet that the process of utilization review involves something more than a mere financing question. The Corcoran court understood that United took the plan of care recommended by Corcoran's obstetrician (round-the-clock inpatient monitoring), evaluated it with its independent medical expertise, and prescribed an alternate treatment plan (intermittent home nursing care) that the patient could not realistically refuse. ${ }^{55}$

Notwithstanding this recognition, the court refused to allow the Corcorans to proceed to trial on a malpractice theory. Although it did believe the Corcorans' contention that the utilization review decisions were medical in

50. Id. at $1323-24,1330$.

51. Pilot Life, 481 U.S. at 47.

52. See, e.g., Independence HMO v. Smith, 733 F. Supp. 983 (E.D. Pa. 1990) (holding that ERISA preemption does not bar action against HMO for physician's malpractice based on "ostensible agency" liability theory).

53. Corcoran, 965 F.2d at 1331.

54. Id. at 1332 (footnote omitted).

55. Id. 
nature, the court agreed with United that the ultimate purpose of these decisions was to adjudicate claims for benefits. "United makes medical decisions as part and parcel of its mandate to decide what benefits are available under the Bell plan," it wrote. "When United's actions are viewed from this perspective, it becomes apparent that the Corcorans are attempting to recover for a tort allegedly committed in the course of handling a benefit determination." ${ }^{956}$ The court thus concluded that ERISA preempted the Corcorans' lawsuit under the Supreme Court cases mentioned above. It buttressed its holding with the observation that preemption would be consistent with Congress's goal in adopting ERISA of "'ensur[ing] that plans and plan sponsors would be subject to a uniform body of benefit law' and 'minimiz[ing] the administrative and financial burdens of complying with conflicting directives among States or between States and the Federal Government."'57 The court reasoned that making utilization review companies follow the states' various malpractice laws would so complicate the review process that it would become prohibitively expensive and consume plan resources otherwise available for benefits. ${ }^{58}$ With much hand-wringing, the court admitted that its opinion left the Corcorans without a remedy for what was probably a very serious error on the part of the defendants, but it noted that the task of amending ERISA to bring it in line with institutional changes in medicine and insurance belonged to Congress, not the courts. ${ }^{59}$

The court's particular resolution of the case was certainly plausible, but it was not foreordained. The outcome did not turn on any aspect of ERISA law itself; rather, the ruling in the case was entirely a function of how the court chose to characterize the facts before it. The court preempted the Corcorans' lawsuit when it tied the actions of United's independent medical staff to Bell's decision to provide insurance coverage, not when it interpreted ERISA. Alternative characterizations of the facts do not present the question of coverage as the salient issue. One could say instead that Bell had already determined that Florence Corcoran was entitled to an appropriate plan of medical treatment before any of the events giving rise to the lawsuit (which did not even name Bell as a defendant) took place. What Florence Corcoran challenged was United's decision, based upon its own independent medical expertise, that a different plan of treatment would be more appropriate for her than the one originally prescribed by her physician. United certainly made this

56. Id.

57. Id. (quoting Ingersoll-Rand Co. v. McClendon, 111 S. Ct. 478, 484 (1990)).

58. Id. at 1333-34.

59. Id. at 1338-39. Towards the start of the litigation, Bell paid Corcoran all of the disability and hospitalization benefits it might have owed her in one lump sum; accordingly, there was nothing additional she could recover under the terms of the benefits contract. Damages for pain and suffering sounded in tort, not in contract or trust law, and were thus not available under ERISA. Id. at 1334-35. Finally, Corcoran could not recover for breach of fiduciary duties under ERISA $\$ 404$ and $\$$ 502(a)(3) as there was no true doctor-patient relationship between her and United. Id. at 1338. 
decision on the assumption that the patient would follow this substituted prescription. So characterized, the case would be purely about the negligent exercise of medical authority, which is arguably beyond the scope of ERISA. ${ }^{60}$

The decision as it stands certainly makes for dubious national policy, extending as it does to the $65 \%$ of all employers in the country who self-insure under ERISA's auspices. ${ }^{61}$ The Corcoran court itself recognized that its rule would shield ERISA-plan utilization review companies from the costs of their medical mistakes, perhaps with dangerous consequences: it would weaken deterrence against future substandard decisionmaking by these firms, and it would mute the incentives for insurers to seek out cost-management companies that can deliver high-quality review services at reasonable prices. ${ }^{62}$ Workers in self-insured firms now cannot receive compensation for medical injuries traceable to the way their health plans manage plan resources. ${ }^{63}$ As for the court's stated policy justification for its ruling, the need to avoid undue administrative burdens, it is not clear that requiring a health plan's utilization reviewer to abide by state medical malpractice laws would be any more burdensome than requiring the same of the plan's staff- or group-model HMO's or of the surgeons retained by the plan to give second opinions prior

60. See, e.g., Independence HMO v. Smith, 733 F. Supp. 983, 988 (E.D. Pa. 1990) (holding ERISA does not preempt claim against multistate HMO for negligence of group physician); DeGenova v. Ansel, 555 A.2d 147, 150 (Pa. Super. Ct. 1988) (holding ERISA does not bar claim against insurer for malpractice during required second surgical opinion). But see Ricci v. Gooberman, No. CIV.A.93-1013(SSB), 1993 WL 551053 (D.N.J. Dec. 28, 1993) (holding ERISA preempts claim against HMO for vicarious liability for contracted physicians' negligence).

Elsesser v. Hospital of the Philadelphia College of Osteopathic Medicine, 802 F. Supp. 1286 (E.D. Pa. 1992), decided shortly after Corcoran, also illustrates how focusing on different subsets of the underlying facts can yield different results for ERISA preemption. In Elsesser, the patient went to her primary care physician (chosen from her HMO's list) after feeling chest pain. The doctor ordered the use of a monitor but discontinued use the next day without reading the results when the HMO refused to pay for it. The patient complained again of pain and was given medication but not referred to a specialist; the next day she suffered a heart attack that left her in a coma. As the patient's guardians, the plaintiffs sued the HMO on three main theories: one alleging vicarious liability for the negligence of the physician, a second alleging direct corporate negligence for failure to screen out the negligent provider, and a third challenging the HMO's decision not to pay for the monitor, which allegedly caused the physician to misdiagnose the severity of his patient's heart condition. Id. at 1290-91. The court held that the first two causes of action were related to providers' traditional negligence and malpractice obligations and were thus beyond ERISA's scope; the third, however, was a challenge to a determination of plan benefits and was thus preempted. Id. at 1290-92.

61. 1 Foster Higgins, 1991 Health Care Benefts Survey 36 (1992).

62. Corcoran, 965 F.2d at 1338; cf. Mark A. Hall \& Gerard F. Anderson, Health Insurers' Assessment of Medical Necessity, 140 U. PA. L. REv. 1637, 1672-73 (1992) (arguing that health care payors' obligation to abide by professional medical standards of care is a significant protection of plan beneficiaries against payor self-interest).

63. Before Corcoran, several commentators had speculated that cases like Wilson would open the way for plaintiffs to receive compensation for medical injuries as damages consequential to a breach of contract, even under ERISA. See, e.g., Hall \& Anderson, supra note 62, at 1662 \& n.91. The Corcoran court's holding that tort-like damages are not available as make-whole relief under ERISA makes such compensation unlikely. Corcoran, 965 F.2d at 1334-37. 
to surgery. Courts have allowed malpractice claims to proceed in both of these situations, ERISA notwithstanding. ${ }^{64}$

Still, the Corcoran decision is notable for its explicit recognition of the medical nature of some cost-containment decisions. Had the malpractice claims proceeded to trial, the jury would presumably have evaluated the utilization review company's determination against the prevailing standards of care required of physicians. Language in the opinion acknowledging the medical component of utilization review and attempting to situate the Corcorans' cause of action within traditional principles of state tort law suggests that the court would have judged the alternative plan of care prescribed by United's medical experts in the same way as it would the original treatment plan devised by Corcoran's obstetrician. ${ }^{65}$

These three cases represent the courts' first attempts to deal directly with the interaction between the new private cost-containment programs and traditional medical practice. Certainly more examples will follow as courts begin to recognize causes of action for payor malpractice independent from the contract- and insurance-law doctrines that have served as shells for such claims in the past ${ }^{66}$ and as plaintiffs broaden their attacks and begin to challenge the indirect "chilling" effects of utilization controls on medical practice in addition to the particular review decisions applying cost criteria to their plans of treatment. ${ }^{67}$ What these cases illustrate fairly dramatically is that the new mechanisms for encouraging more cost-effective medical practice directly intrude into what the tort law has traditionally considered "medical authority" and reshuffle the values balanced in the concept of "malpractice." The courts' difficulties in assigning liability and articulating duties of care in these cases are a direct result of a new medical practice culture clashing against an old legal paradigm. The next section of this Note seeks to provide a better sense of the dimensions of this conflict by fleshing out the cultural picture of

64. See cases cited supra note 60 .

65. See, e.g., Corcoran, 965 F.2d at 1326-28, 1331.

66. Courts and plaintiffs reluctant to press direct claims for medical negligence against third-party payors have often recast them as more traditional claims for tortious breach of contract or bad-faith denial of insurance benefits. See, e.g., Williams v. HealthAmerica, 535 N.E.2d 717, 719 (Ohio Ct. App. 1987) (suit for injuries resulting from HMO physician's failure to timely diagnose illness and refer to specialist framed as action for breach of insurer's duty to adjudicate claims in good faith). The issue of a third-party payor's direct liability for something approaching medical malpractice arose so starkly in the three cases discussed in the text because in each, the plaintiffs decided not to sue the treating physician; as a result, the health plans stood as the only actors upon which legal blame for the medical error could be pinned.

67. In a much noted (though unpublished) Michigan case, a court allowed a plaintiff to proceed against an HMO for injuries allegedly resulting from a gatekeeper's refusal to refer the plaintiff to a gynecologist. The court found that a genuine issue of fact existed as to whether the HMO's utilization controls and financial risk-pooling arrangements designed to discourage excessive testing and specialist referrals were responsible for a delay in diagnosing and treating the plaintiff's cervical cancer. Bush v. Dake, No. 8625767 NM-2, slip. op. at 3-4 (Saginaw County Cir. Ct. Apr. 27, 1989). The defendants settled following the denial of summary judgment. 
medical decisionmaking and professional authority implicit in our law of medical malpractice.

\section{Malpractice LAW AND the New PRActice Culture: UNDERSTANDING WHAT HAS CHANGED}

\section{A. Cost-Consciousness and the Physician's Duty of Care}

As discussed above, the law does not hold physicians responsible for all injuries that their patients suffer in the course of medical treatment; rather, physicians are only liable for conduct that falls below a certain standard of care. That standard is generally defined by reference to the usual and customary practice among medical providers in the same specialty and in similar circumstances. ${ }^{68}$ Whereas a lay jury in an ordinary negligence case may simply rely on its own knowledge to determine the conduct of the "reasonably prudent person in similar circumstances," the standard of care in a medical malpractice trial must be established by expert witnesses. ${ }^{69}$

Malpractice doctrine's focus on usual and customary practice reflects the belief that there is a "best way" to practice medicine, one that is supported by a professional and scientific consensus. ${ }^{70}$ Courts allow few exceptions to this unitary standard of care. ${ }^{7}$ For the most part, if a physician deviates from this standard and her patient is injured, the patient may recover if the deviation was the cause of the injury.

Although the courts never say so directly, this duty of care embodied in malpractice doctrine seems to obligate physicians to make their medical decisions without regard to the cost (or cost-effectiveness) of the treatments or

68. See W. PAge Keeton et AL., PROSSER AND Keeton ON THE LAW OF TORTS § 32, at 185-93 (5th ed. 1984). On rare occasions, courts have held physicians to a higher standard of conduct than that currently exercised in the profession; in such cases, they rely on the standard of the "reasonably prudent physician." See, e.g., Nesbitt v. Community Health of S. Dade, 467 So. 2d 711, 714-15 (Fla. Dist. Ct. App. 1985); Helling v. Carey, 519 P.2d 981, 983 (Wash. 1974).

69. See, e.g., Bell v. Maricopa Medical Ctr., 755 P.2d 1180, 1182 (Ariz. Ct. App. 1988) (comparing ordinary negligence and medical malpractice duties of care).

70. See Blumstein, supra note 13 , at 89,91 .

71. The exceptions are for situations where alternative practice styles are each supported by a degree of consensus. For example, a physician may defend her actions by demonstrating that there were "two schools of thought" on the problem or that she followed the practices of a "respectable minority." See, e.g., Levine v. Rosen, 616 A.2d 623, 627 (Pa. 1992); Downer v. Veilleux, 322 A.2d 82, 87 (Me. 1974).

Similarly, under the "locality rule," the standard of care could vary geographically to take account of resource constraints facing an entire practice community. Although several courts still follow some form of this rule, see, e.g., Leiker v. Gafford, 778 P.2d 823, 842 (Kan. 1989) (requiring doctors to exercise degree of learning and skill possessed by physicians in same or similar community), the doctrine is on its way out; courts are increasingly holding all physicians to the same standard of care. See, e.g., McDaniel v. Hendrix, 401 S.E.2d 260, 262 (Ga. 1991); Bates v. Meyer, 565 So. 2d 134, 136 (Ala. 1990); Hall v. Hilbun, 466 So. 2d 856, 871-72 (Miss. 1985). The focus of the doctrine is on the practice patterns of the community as a whole; the standard of care is never adjusted for differently situated individuals or health plans within a single community. See E. Haavi Morreim, Cost Containment and the Standard of Medical Care, 75 CAL. L. REv. 1719, 1729-31 (1987). 
tests they are prescribing. Once a physician accepts a patient for treatment, for example, she becomes the patient's fiduciary. ${ }^{72}$ She may not vary the kind or degree of care she provides because of her patient's financial status. As one court has said,

Whether the patient be a pauper or a millionaire, whether he be treated gratuitously or for reward, the physician owes him precisely the same measure of duty, and the same degree of skill and care. He may decline to respond to the call of a patient unable to compensate him; but if he undertake the treatment of such a patient, he cannot defeat a suit for malpractice, nor mitigate a recovery against him, upon the principle that the skill and care required of a physician are proportioned to his expectation of pecuniary recompense. ${ }^{73}$

As a part of this duty to the patient, the physician must exercise due care in diagnosis; some courts have held that a doctor's failure, for whatever reason, to take advantage of all available diagnostic tests can constitute negligence. ${ }^{74}$ The physician's prescription of a course of treatment is equally circumscribed. If she omits a procedure simply because it would more likely than not be ineffective, she risks liability for her patient's "lost chance" of recovery. ${ }^{75}$ And in some cases, courts have gone so far as to order a physician to supply medical treatment that she thinks is futile, citing the need to preserve patient autonomy within the fiduciary relationship. ${ }^{76}$

72. See, e.g., Tracy v. Merrell Dow Pharmaceuticals, Inc., 569 N.E.2d 875, 879 (Ohio 1991) (holding physician-patient relationship to be fiduciary one based on trust, confidence, and good faith); Black v. Littlejohn, 325 S.E.2d 469, 482 (N.C. 1985) (same); see also Maxwell J. Mehlman, The Patient-Physician Relationship in an Era of Scarce Resources: Is There a Duty To Treat?, 25 CONN. L. REV. 349, 367 n.66 (1993).

73. Becker v. Janinski, 15 N.Y.S. 675, 677 (C.P. N.Y. City \& County 1891); see also Tunkl v. Regents of Univ. of Cal., 383 P.2d 441, 448 (Cal. 1963) (finding suggestion that hospital's duty of care to charity patients less than duty to paying patients as "abhorrent"); President of Georgetown College v. Hughes, 130 F.2d 810, 812-13, 827 (D.C. Cir. 1942) (rejecting hospital's claim of immunity from injuries committed on nonpaying patients); Morreim, supra note 71, at 1724-25; John A. Siliciano, Wealth, Equity: and the Unitary Medical Malpractice Standard, 77 VA. L. REV. 439, 441-42 (1991).

74. See, e.g., Forrestal v. Magendantz, 848 F.2d 303 (1st Cir. 1988); Clark v. United States, 402 F.2d 950, 952 (4th Cir. 1968); Wilkinson v. Vesey, 295 A.2d 676, 683 (R.I. 1972); Smith v. Yohe, 194 A.2d 167, 173 (Pa. 1963). But see Durr v. McElrath, 382 S.E.2d 20, 22 (S.C. Ct. App. 1989) (rejecting jury instruction stating that failure to perform all tests constitutes negligence).

75. See, e.g., Falcon v. Memorial Hosp., 462 N.W.2d 44 (Mich. 1990) (allowing plaintiff to recover for failure to perform procedure which would have had, at most, $37.5 \%$ chance of avoiding injury); Herskovits v. Group Health Coop. of Puget Sound, 664 P.2d 474 (Wash. 1983) (allowing action for wrongful death to stand where negligent delay in diagnosis reduced patient's chance of survival from $39 \%$ to $25 \%$ ).

One should note, however, that the loss of a chance doctrine is not necessarily cost-ineffective. A procedure with less than a 50\% chance of success will still have a positive expected value if the benefit to be gained discounted by the probability of success is greater than the cost of the procedure.

76. See, e.g., In re Conservatorship of Helga M. Wanglie, No. PX-91-283 (Hennepin County P. Ct. July 1, 1991). This case involved an 86-year-old ventilator-dependent woman in a persistent vegetative state. Although the hospital concluded that further care would be futile and would not advance the patient's personal interest, the family wanted to keep her alive at all costs. The hospital sought to appoint a conservator who could decide the patient's best interests. The court refused, finding this to be an 
Together, these rules suggest a certain image of medical decisionmaking, one in which physicians may only consider therapeutic benefits and harms; judgments of cost-effectiveness are out-of-bounds. There is no general "Learned Hand test" in malpractice law that requires physicians to provide those tests and treatments (and only those tests and treatments) that are costbenefit justified. ${ }^{77}$ Indeed, the law seems to view all economic calculations as a threat to the delicate fiduciary relationship between healer and patient. ${ }^{78}$ According to malpractice doctrine, all individuals who enter a community's health care system are entitled to the exact same standard of care, regardless of their abilities (or the community's ability) to pay for it.

Such doctrine could only survive in a certain economic and institutional context. Recall that physicians may decline to accept patients for any reason at all, including their lack of resources; if a patient is accepted, however, she is entitled to the full duty of care. Given the high degree of medical indigence in this country, the health care system could only afford this legal entitlement and at the same time avoid a crisis of access under conditions of abundant resources and free cross-subsidization of health care. These last conditions would require medical consumers who were relatively insensitive to (or ignorant of) the costs of their care. ${ }^{79}$ This is, of course, a fairly good description of this country's fee-for-service health care economy of several decades ago. The cultural image of medical decisionmaking embodied in malpractice doctrine is thus very much a part of the system of production in which the law matured.

The health care economy has changed, but the doctrine-reflecting a, deeper cultural conception of what medical decisionmaking is supposed to be-has not. Hence the trouble with the new cost-containment programs: utilization controls and financial risk-pooling ask the treating physician to ration care at the point of service according to some notion of costeffectiveness, but malpractice law commands that same physician to ignore the cost of the services she provides. The physician is thus caught between two conflicting sets of marching orders ${ }^{80}$ Courts have not been particularly

infringement of the patient's autonomy. By the time the case went to court, the patient's care had cost Medicare and her private insurance company $\$ 800,000$. Ronald E. Cranford, Helga Wanglie's Ventilator, HASTINGS CENTER REP., July-Aug. 1991, at 23, 23-24.

77. See United States v. Carroll Towing Co., 159 F.2d 169, 173 (2d Cir. 1947) (Learned Hand, J.) (defining negligence by weighing probability and severity of injury against cost of precaution). As mentioned above, however, sometimes a court will perform its own cost-benefit calculation when it believes that current customary practice is below that of the "reasonably prudent physician." See supra note 68 .

78. Cf. Morreim, supra note 71 , at 1727.

79. Siliciano, supra note 73 , at $448-51$.

80. In an amicus brief filed in Wickline, the California Medical Association explained the physician's dilemma in the new cost-conscious practice context:

The patient who is injured when care which should have been provided is not provided will recover from someone. If the third-party payor imposing [cost] controls is permitted to avoid liability by maintaining the fiction that these mechanisms have only fiscal consequences, so that patient care is solely the physician's responsibility, the physician becomes the insurer. If 
sensitive to this dilemma to date. Although they may be willing to extend liability to the third-party payor, as we have seen, they refuse to adjust the physician's duty of care to reflect her practice context. And as Wickline illustrates, a court may even require more of doctors practicing in costconscious systems, imposing upon them an obligation to navigate for their patients through the procedures of the payors' utilization control programs.

The question then becomes what to do next. This cultural image of medical decisionmaking is contingent upon an institutional context that is becoming obsolete. The structural evolution in the health care economy and the agitation for reform are signals that we as a society are no longer able to maintain medical entitlements at the level at which they now exist. Continuing judicial reaffirmations of malpractice doctrine's high standard of care may be brave resistance to these changes, but they serve only to worsen the plight of those who practice in this new environment. For malpractice reform to be meaningful to these actors, it must recognize the economic contingency of the standard of care.

\section{B. Expanding the Locus of Medical Decisionmaking Authority}

Just as malpractice doctrine embodies a certain cultural idea as to what constitutes appropriate medical decisionmaking, it also embraces a definite conception of who in society has the proper authority to make such decisions. The law contemplates a system in which specially trained professionals provide care, lay entities finance it, and there is no overlap between the two. Costcontainment programs blur this division and redistribute what we normally consider "medical authority" to nontraditional actors. In the process, they confront courts with new questions of causal responsibility and liability.

Traditionally, physicians have had a monopoly on the power to define appropriate medical outcomes, but as a result of that monopoly, they bore sole liability for negligent medical decisions. Early in its existence, for example, the modern medical profession consolidated its authority and preserved its autonomy through statutes and common-law rules forbidding the corporate practice of medicine. ${ }^{81}$ These legal rules had (and where they remain in existence, still have) the secondary effect of immunizing health care financing corporations from malpractice liability: if the law deemed an entity incapable of practicing medicine at all, how could it possibly be guilty of practicing

rationing malfunctions, the physician who complies with the program is liable to the patient.

If the physician does not comply, the physician is punished or faces responsibility for incurring unauthorized costs.

Amicus Curiae Brief on Behalf of the Califomia Medical Association in Support of Respondent Lois J. Wickline at 4-5, Wickline v. State, 228 Cal. Rptr. 661 (Ct. App. 1986) (No. B010156).

81. See PAUl STARR, THE SOCIAL TRANSFORMATION OF AMERICAN MEDICINE 204-06, 215-20 (1982). 
negligently? ${ }^{82}$ In the same way, before 1960 most courts agreed that hospitals could not be held vicariously liable for the medical malpractice of their physicians under a theory of respondeat superior. The touchstone of such liability would be the employer's constructive control of its employees' behavior, and lay entities like hospitals were presumed to be incapable of exercising control over skilled medical professionals. ${ }^{83}$ In short, malpractice law governed physicians and physicians alone; all others were exempt from its strictures.

Instead, health care financers were regulated by a separate family of tort doctrines that grew out of the traditional legal obligations of the insurance industry as a whole. Third-party payors, for example, had to adjudicate claims for benefits in good faith or risk liability for the torts of unfair dealing and bad-faith breach of contract. ${ }^{84}$ For the most part, these doctrines simply imposed procedural obligations on the insurer: in processing claims, for example, the payor had to gather all relevant medical documentation, ${ }^{85}$ personally contact the patient's treating physician, ${ }^{86}$ and inform the claimant of contractual rights of appeal if it denied benefits. ${ }^{87}$ Although it could not stray too far from current medical practice in doing so, the third-party payor had authority to make its own judgment of "medical necessity" apart from that of the treating physician. ${ }^{88}$ Even today, courts prefer to use these familiar procedural doctrines to regulate insurance companies rather than invent new ones; hence their tendency, noted earlier, to shoehorn injury claims against health care payors into actions for bad-faith denial of benefits and tortious breach of contract.

82. See, e.g., Williams v. Good Health Plus, Inc., 743 S.W.2d 373, 375-76 (Tex. Ct. App. 1987) (stating that HMO not vicariously liable for its physician's malpractice because it is barred by statute from practicing medicine); $c f$. TEX. REv. CIv. STAT. ANN. art. 4495b $\$ 3.08$ (West Supp. 1993); TEX. INS. CODE ANN, art. 20A.26(c) (West 1993).

83. See, e.g., Rosane v. Senger, 149 P.2d 372, 374 (Colo. 1944); see also L. S. Rogers, Annotation, Liability of Hospital or Sanitarium for Negligence of Physician or Surgeon, 69 A.L.R.2d 305, 322 (1960).

84. See generally JoHn A. APPLEMAN \& JEAN APPLEMAN, INSURANCE LAW AND PRACTICE \$\$ 8877 8879 (1981).

85. E.g., Hughes v. Blue Cross of N. Cal., 263 Cal. Rptr. 850, 857 (Ct. App. 1989); Aetna Life Ins. Co. v. Lavoie, 505 So. 2d 1050, 1052-53 (Ala. 1987).

86. E.g., Linthicum v. Nationwide Life Ins. Co., 723 P.2d 675, 681-82 (Ariz. 1986). But see Mordecai v. Blue Cross-Blue Shield of Ala., 474 So. $2 \mathrm{~d} 95$ (Ala. 1985) (holding that failure to contact physician is not per se insurer bad faith).

87. Sarchett v. Blue Shield of Cal., 729 P.2d 267, 277 (Cal. 1987).

88. See, e.g., id. at 273; Franks v. Louisiana Health Serv. \& Indem. Co., 382 So. 2d 1064 (La. Ct. App. 1980). But cf. Hughes, $263 \mathrm{Cal}$. Rptr. at 857 (explaining that insurer need not defer to treating physician, but it may not use definition of medical necessity "significantly at variance with the medical standards of the community"; such use would violate policyholder's expectations in signing insurance contract).

This independent power to define medical necessity may be more theoretical than real. Hall \& Anderson, supra note 62 , at $1647-48$, note that while courts regularly reaffirm the authority of insurers to define medical necessity, they override those definitions with equal regularity in determining the scope of coverage. Even in such cases, however, the insurers' judgments are overturned because of supposed procedural deficiencies (such as contractual ambiguities or defects in gathering patient information), not because of a lack of substantive power to make judgments of medical necessity. See id. at 1648 n.35. 
But an obvious separation between professional providers and lay financers no longer exists. What cases like Corcoran demonstrate fairly dramatically is that third-party payors, in the context of managed-care arrangements, often make decisions that we would normally consider to be medical ones. Utilization review companies evaluate a treating physician's plan of care using their independent medical expertise; in addition, they suggest alternative courses of treatment with the knowledge and expectation that most patients will follow their prescriptions. These arrangements diffuse medical authority among a number of actors, causing difficulties for courts working within a doctrinal model that posits a single medical decisionmaker.

This diffusion of power in the managed-care setting is part of a much broader trend. In recent years, the medical profession's monopoly on the authority to define appropriate health care outcomes for society has been severely eroded. We have come to realize that questions of "medical necessity" and "essential care" cannot be resolved by objective medical science alone: they necessarily involve disputes over individuals' claims to social resources. $^{89}$ We delegated these questions to the medical profession in the past, but the recent push for cost containment is an expression of dissatisfaction with the job that the profession has done. The governmentsponsored movement to catalogue the clinical effectiveness of commonly prescribed medical treatments, for example, is premised on the idea that physicians, applying their own criteria of therapeutic benefit and harm, have developed irrational patterns of practice that society cannot afford. ${ }^{90}$ Businesses and health care payors are likewise beginning to draft their own sets of medical practice protocols with an eye towards encouraging costeffective care; the results of these endeavors usually differ markedly from the clinical guidelines developed by the profession on its own. ${ }^{91}$ Efforts such as Oregon's initiative to develop a priority-ranked list of medical treatments for its Medicaid program reffect a sentiment that matters of medical decisionmaking are properly the subject of broad-based social negotiation

89. See, e.g., Daniel Callahan, Medical Futility, Medical Necessity: The-Problem-Without-A-Name, HASTINGS CENTER REP., July-Aug. 1991, at 30, 30-31; David M. Eddy, What Care Is "Essential"? What Services Are "Basic"?, 265 JAMA 782, 782-86 (1991).

90. See John E. Wennberg, Outcomes Research, Cost Containment, and the Fear of Health Care Rationing, 323 NEW EN̦G. J. MED. 1202, 1203-04 (1990) (outcomes-research legislation intended to investigate inexplicable and costly practice variations across communities and to increase patients' power vis-à-vis physicians by generating information).

91. See Eleanor.D. Kinney et al., Report of the Medical Guidelines Panel, in INSTITUTE FOR CIVIL Justice, HeAlTH CARE DELivery AND TORT: SySTEMS ON A COLlision COURSE? 46, 53 (Elizabeth Rolph ed., 1992); Mark A. Hall, The Defensive Effect of Medical Practice Policies in Malpractice Litigation, LAW \& CONTEMP. PROBS., Spring 1991, at 119, 121-26 (describing efforts to draft medical practice policies initiated outside medical profession); Anita J. Slomski, Business to Doctors: Show Us You're Doing It Right, MED. ECON., Aug. 9, 1993, at 70, 72-74 (describing outcomes research and guideline-drafting activities of Business Health Care Action Group, an alliance of 14 Minnesota-based corporations). 
involving members of the lay public..$^{22}$ The set of actors that may now legitimately exercise some social authority to define appropriate health care outcomes has thus been greatly expanded.

But if physicians have lost their monopoly on medical authority, they have also lost their monopoly on liability: as medical decisionmaking authority has become more diffuse, courts have expanded the universe of potential targets of malpractice actions. Recognizing the role that the modern hospital plays in determining a patient's medical experience, courts have done away with the old rule immunizing them from vicarious liability for the malpractice of their physicians. ${ }^{93}$ Likewise, many jurisdictions now hold managed-care organizations liable for their physicians' malpractice on similar theories of agency, old doctrines forbidding the corporate practice of medicine notwithstanding. ${ }^{94}$ For both hospitals and HMO's, courts have created new torts of corporate negligence in recognition of the independent role these organizations play in structuring the patient's initial selection of a practitioner. ${ }^{95}$

Cases like Wickline, Wilson, and Corcoran are a part of this same trend. The cases represent tentative first steps in expanding liability to cover the new entrants into the field of medical decisionmakers: the third-party payors and utilization review companies that work alongside the treating physician and look over her shoulder when she prescribes care. But the courts are still not sure how these cost-conscious actors fit into the traditional malpractice scenario. When it came down to the facts, the Wickline court put the utilization controls squarely on the payor side of the provider-payor divide, construing medical decisionmaking very narrowly and holding cost-managers to the insurers' old duties of good faith and fair dealing. The Corcoran court, on the other hand, was fairly certain that the utilization review company's determination was a medical decision, one that shadowed the judgment exercised by the patient's treating physician, and one (presumably) that would

92. Charles J. Dougherty, Setting Health Care Priorities: Oregon's Next Steps, HASTINGS CENTER REP., May-June 1991 (Supplement: Conference Report) at 1, 6 (describing role of community meetings in setting priority list); David C. Hadom, The Oregon Priority-Setting Exercise: Quality of Life and Public Policy, HASTINGS CENTER REP., May-June 1991 (Supplement: Conference Report), at 11 (describing ranking methodology).

93. See, e.g., Bing v. Thunig, 143 N.E.2d 3 (N.Y. 1957) (holding hospital to same respondeat superior liability as any other employer); see also Diane M. Janulis \& Alan D. Hornstein, Damned If You Do, Damned If You Don't: Hospitals' Liability for Physicians' Malpractice, 64 NEB. L. REV. 689 (1985).

94. E.g., Schleier v. Kaiser Found. Health Plan, 876 F.2d 174, 177-78 (D.C. Cir. 1989) (per curiam); Sloan v. Metropolitan Health Council, 516 N.E.2d 1104 (Ind. Ct. App. 1987).

95. See, e.g., Harrell v. Total Health Care, Inc., No. WD 39809, 1989 WL 153066 (Mo. Ct. App. 1989), aff'd on other grounds, 781 S.W.2d 58 (Mo. 1989) (allowing suit against HMO in absence of statutory immunity for gatekeeper's negligence in referring patient to unqualified specialist); Darling v. Charleston Community Memorial Hosp., 200 N.E.2d 149 (Ill. App. Ct. 1964), aff'd, 211 N.E.2d 253 (IIl. 1965), cert. denied, 383 U.S. 946 (1966) (holding hospital liable for retaining unqualified emergency room physician); see also William A. Chittenden, III, Malpractice Liability and Managed Health Care: History and Prognosis, 26 TORT \& INS. L.J. 451, $468-73$ (1991). 
be evaluated by the same duty of care. Finally, the Wilson court dodged the question entirely: it assigned liability as soon as it found causation, not bothering to explain whether a medical error or a breach of the insurance contract constituted the necessary violation of duty. Taken together, these three cases suggest that any future cost-containment efforts will be subject to some kind of liability for the medical injuries that they may cause-how broad that liability will be, however, and upon what theory it will be premised are still unclear.

\section{SOME LESSONS FOR COURTS AND POLICYMAKERS}

\section{A. The Necessary Elements of a Solution}

It is clearly a mistake to talk about a new round of cost-containment efforts without reference to the existing tort system; it is equally wrong to plan for tort reform without anticipating the major changes in practice style that cost containment is intended to bring. Far from being two separate issues rolled into the same piece of legislation just for political expediency, cost control and malpractice law are intimately linked. A meaningful cost-containment program-one that will force practitioners to eliminate marginally beneficial care that is not in some sense cost-effective-will cut directly across the tort system's command to provide quality medical care without regard to costs and resource constraints. Physicians, then, will be caught in a double bind: we will take away the resources they need to maintain the current standard of care, but we will not excuse them for failing to meet it. Physicians might obtain some relief if patients injured by rationing decisions were able to collect from their health plans, but such relief would be assured only if the courts were prepared to embrace the idea that the process of utilization review itself constituted a kind of medical decisionmaking not subject to the usual statutory and commonlaw protections of the insurance industry. Without such a policy, physicians would be secure from liability only to the extent that their injured patients could recast their claims as bad-faith breaches of contract and could avoid the broad sweep of ERISA preemption.

Most of the tort reforms currently on the table-caps on jury awards, changes in the collateral-source rule, mandatory arbitration prior to litigation-would not alleviate the physician's plight. The problem is that the analyses of the malpractice system upon which these solutions are based simply view the tort system as a black box: a machine that processes inputs (facts and legal resources) into outputs (compensation, punishment, and deterrence). They do not look at doctrine, the set of decision rules that drives the processing. These reforms merely modify the tort machine's inputs and outputs. Caps on jury awards and denial of double recoveries mitigate the severity of the system's outputs, while mandatory arbitration seeks to screen 
its inputs. But as we have seen, the roots of the physician's dilemma lie in the content of malpractice doctrine, and this remains unchanged.

Even some of the more ambitious proposals for reform-elective no-fault schemes that encourage defendants to settle quickly and on favorable terms, ${ }^{96}$ selective no-fault systems that speed recovery for a limited and predefined set of medical outcomes usually associated with physician wrongdoing, ${ }^{97}$ and plans for replacing juries with administrative panels of medical experts $^{93}$ - likewise leave malpractice doctrine basically intact. These schemes merely attempt to expedite the processing of inputs into outputs by removing the "easy cases" from the queue. The tort system, or at least the fault-based rules of tort, survives as the backstop for the new scheme if it should find itself unable to process a given case.

Looking at doctrine, as this Note has done, suggests other avenues of malpractice reform. A recognition of the economic and institutional contingency of the legal standard of care required of physicians suggests that allowing variations in that standard is a necessary element of meaningful malpractice reform. Although other commentators have argued strenuously to the contrary, ${ }^{99}$ the idea that a physician's duty of care might vary with her practice context or with her patients' resources is not so draconian as it might first sound. The duty of care has two parts: the set of medical procedures that the doctor must perform with respect to a given patient, and the degree of skill with which she must perform those procedures. Proposals to vary the standard of care only address the first component-the menu of treatment entitlements. Nobody suggests that physicians should be allowed to practice carelessly with respect to their poorer patients. ${ }^{100}$

Simply varying the set of procedures that a physician is legally obligated to provide in a given situation, however, will not be enough. Creating some form of explicit cost-containment justification for substandard care might loosen the binds of the practitioner, but it does nothing for the patient who has been injured by a deficient rationing decision. In addition, a simple extension of immunity for cost-motivated decisions would destroy what little accountability currently exists for the third-party payors whose aggressive management of their beneficiaries' courses of treatment has blurred traditional notions of medical decisionmaking authority.

96. E.g., O'Connell, supra note 6, at 95-100.

97. E.g., Tancredi \& Bovbjerg, supra note 6, at $185-91$.

98. E.g., Kirk B. Johnson et al., A Fault-Based Administrative Alternative for Resolving Medical Malpractice Claims, 42 VAND. L. REV. 1365 (1989).

99. See, e.g., Note, Rethinking Medical Malpractice Law in Light of Medicare Cost-Cutting, 98 HaRv. L. REV. 1004, 1019 (1985) (arguing that lowering standard of care would "offend redistributive and humanitarian values," "intensify social inequities," and "pervert the "caring' ideal in health care").

100. See Siliciano, supra note 73 , at $476-77$. In addition, it may be more humane to increase access to the health care system by decreasing the set of procedures a doctor must perform if she accepts a patient than it would be to preserve a full set of entitlements for those very few who will be given access to the present system. Id. at $459-60$. 
The fact that responsibility for making medical decisions is now frequently shared between professional and lay entities suggests that the liability that has traditionally accompanied the exercise of medical authority should be extended to the new entrants to the field. A movement to some form of enterprise liability, in which legal responsibility for health care outcomes would be fully or partially transferred to the health plan under which treatment was provided, would respond to this diffusion of medical authority. It would thus correct for malpractice law's narrow view of medical authority and its rigid distinction between payors and providers.

But just as it would not be enough simply to vary the standard of care required in malpractice suits, the extension of liability to third-party payors who exercise medical authority would not, without more, be sufficient. Allowing malpractice-based suits against the health plan but preserving the existing economics-blind duty of care would relieve the pressures on physicians and compensate injured patients, but only at the cost of sacrificing meaningful cost containment. ${ }^{101}$ Some combination of the two approaches-accounting for shared causation and modifying the standard of care-is therefore needed.

\section{B. A Two-Step Inquiry into Medical and Quasi-Medical Negligence}

I now suggest one possible form that such a combination might take, framed as a two-step inquiry a court could use to resolve some of the convoluted medical malpractice cases that arise in the new practice culture. It is a solution that has its roots, surprisingly enough, in Wilson v. Blue Cross-the most confused of the utilization review cases considered earlier. I do not pretend that such a solution should be expected to arise spontaneously from the judiciary. As I argue below, some of the more far-reaching aspects of this solution may be beyond the competence of courts to enact on their own; in any event, the existing doctrine may be too deeply rooted to abandon without legislative action.

Implicit in the Wilson court's jumbled opinion are two distinct lines of inquiry. First is the question of whether or not the medical treatment that the patient received-regardless of who was actually responsible for prescribing that treatment-met the standard of care required of practitioners. Separate from this is a question of causation: Which actor was responsible for defining this course of treatment? The Wilson court's error was to blur the two issues; as a result, it was unclear whether the court assigned liability to the insurer on the basis of medical negligence or contractual breach.

101. Cf. Hall \& Anderson, supra note 62, at 1658-61 (arguing that cost containment is impossible if in coverage disputes insurers are required to fund same inflated menu of care that physicians are currently required to provide). 
A court reviewing a case of possible medical malpractice where the actions of third-party payors are at issue should explicitly separate the two lines of inquiry. Its first step should be to evaluate the sufficiency of the course of treatment that the patient actually received, putting aside for the moment the question of how that plan of treatment was negotiated. Here the court should take the patient's treatment plan as if it were prescribed by a single actor and measure it against a standard of care representing a substantial agreement of providers who work within a similar practice context. The standard would be established by the testimony of experts competent to discuss the particular practice context or, if current plans to aggregate consumers into powerful insurance-purchasing cooperatives went into effect, by contract. Only when a court found collective medical negligence would it proceed to the next step: parceling out causal responsibility among the various actors. The court should adopt a weak form of enterprise liability, holding all entities whose conduct constituted a substantial factor in determining the final prescription of treatment jointly and severally liable for the injuries caused by that prescription.

\section{Step One: Evaluating the Actual Course of Treatment}

The first phase of the analysis would simply determine the existence of liability for medical negligence without looking at how that liability should be apportioned. At this stage the court should assume that the course of care the patient actually received was prescribed by a single medical decisionmaker; after all, from the injured patient's perspective, it matters little whether the treatment received was the result of a single physician's coherent plan of action or of multiple rounds of bargaining and compromise between numerous practitioners and payors. The question is then as follows: If a single actor had prescribed the course of treatment actually received by the patient, would that actor have breached her duty of care? If not, the inquiry ends, for there has been no medical negligence. Only when that hypothetical single actor would have violated the standard of care owed to patients should the court proceed to apportion liability.

Of course, this does not address the standard of care to which the assumed single decisionmaker should be held. As discussed above, there must be some variation from the unitary high standard courts currently use in order to ease the burdens of physicians practicing in cost-conscious contexts. One commentator has suggested that the unitary standard of care be turned into a rebuttable presumption: a physician operating under resource constraints who deviated from the unitary standard could, by introducing evidence about the practice context, demonstrate that the substandard care was the result of 
necessity rather than negligence. ${ }^{102}$ But this approach seems better tailored to the acute resource constraints faced by inner-city public hospitals than to the general, system-wide pressures for cost containment that are the subject of this Note. Rarely in these cases can it be said that the third-party payor's substitution of an alternative course of treatment is truly necessary; rather, it is simply desirable, as it allows health-plan resources to be freed for patients with greater medical need. It might be possible instead to relax the concept of "necessity" and allow physicians to defend against the omission of care simply by arguing that the omitted treatment was not cost-benefit justified, but we must recognize that such a standard would increase the complexity of malpractice suits. ${ }^{103}$

Simpler solutions are possible. Rather than saddle the court with an unanchored inquiry into the cost-benefit justification of a given medical practice, a less stringent form of the customary practice rule could be preserved, one more attuned to cost-motivated changes in practice style. Such a rule would hold that the hypothetical single actor would be negligent only if she prescribed a plan of care that was not supported by a substantial agreement of physicians operating in a similar practice context. ${ }^{104}$ The existence or absence of this support would be demonstrated by the testimony of experts who normally practiced in (or were otherwise found competent by the court to discuss) the particular institutional setting in which the patient received her care. This new rule would make these institutional and economic criteria an explicit focus of the court's inquiry. At the same time, it would preserve the familiar form of the malpractice suit, simply refocusing the existing inquiry into customary practice by modifying the use of expert testimony.

This rule would allow the standard of care (again, taken as the set of medical procedures to which a patient is entitled, not the degree of skill with which those procedures must be performed) to vary among families of caredelivery arrangements: different standards could apply in the context of privately funded fee-for-service plans, capitated managed-care arrangements,

102. Morreim, supra note 71 , at $1757-63$.

103. Two of the reform packages currently before Congress take this tack. Both the Bipartisan Group on Health Reform's bill and the House Republican bill propose a uniform standard of negligence framed as a free-floating inquiry into the reasonableness of practitioners' conduct. H.R. 3222, 103d Cong., 1st Sess. § 5109(a) (1993); H.R. 3080, 103d Cong., 1st Sess. § 2016 (1993).

104. Although this formulation is mine, it bears some resemblance to the "respectable minority" and "similar locality" rules that currently exist in malpractice law to support minor variations from the national, unitary standard of care. See supra note 71. Despite suggestions from commentators that these already existing doctrines provide the law with the flexibility necessary to account for differences in health care delivery arrangements, e.g., Randall Bovbjerg, The Medical Malpractice Standard of Care: HMOs and Customary Practice, 1975 DuKE L.J. 1375; Mark A. Hall, The Malpractice Standard Under Health Care Cost Containment, 17 LAW MED. \& HEALTH CARE 347 (1989), courts have never used them to vary the standard of care for purely economic concerns. See Morreim, supra note 71, at 1729-31, 1736 (arguing that similar locality and respectable minority rules as currently formulated are incapable of addressing costcontainment concerns). 
and publicly funded health-assistance programs, for example. The need for independent and competent expert testimony, however, probably prevents more finely grained variations than this. ${ }^{105}$ While such family-wide modifications in the duty of care would certainly be an improvement over the status quo, imposing a uniform standard-even a more lenient one-upon the entire range of plans that fell into a single institutional class would still be problematic. With the classes defined broadly, there is a risk that all of the plans within a given class would be held to the highest standard of practice found in any one of them, despite the intention of any individual plan to pursue a more aggressive program of cost containment in order to offer its members lower premiums. For example, testimony in a malpractice case that a different capitated HMO (one with higher premiums, presumably) provided a more extensive menu of treatment options to patients with the plaintiff's medical condition than did the defendant HMO could prove fatal in the eyes of the jury, even though the defendant HMO's beneficiaries may have agreed when joining the plan that it was wcrthwhile to accept a more limited range of treatment options in exchange for lower insurance premiums. ${ }^{106}$

Ideally, then, the standard of care would be variable at the level of the individual health plan. This would require a legal regime that allowed beneficiaries and insurers to bargain over the duty of care in the insurance contract and that encouraged courts to defer to that bargain. Plan beneficiaries could establish a more restrictive standard of care (or even a more generous one, should they be willing to pay for it) through contract language that either explicitly defined the decision rule to be applied in cases alleging negligent medical injury ${ }^{107}$ or made reference to a set of medical guidelines or practice protocols as a way of defining the procedures that a physician is obligated to provide to a given patient. ${ }^{108}$

105. This method could not be used to establish a standard of care particular to a single health plan, for example, because the only experts who could testify about that standard would be in the employ of the defendant plan itself. More generally, the need to find competent, yet independent, experts prevents the litigants from defining the relevant universe of health plans too narrowly.

106. For arguments that it is entirely reasonable for a group of insurance beneficiaries to agree that it would not be worthwhile to insure against all health risks or cover all medical procedures, see Hall \& Anderson, supra note 62, at 1676-80; Clark C. Havighurst, Prospective Self-Denial: Can Consumers Contract Today To Accept Health Care Rationing Tomorrow?, 140 U. PA. L. REV. 1755, 1771-72 (1992). These beneficiaries would receive lower actuarial premiums in exchange for their agreement to forego the level of benefits otherwise available. The bargain would still be reasonable ex ante (and, these authors argue, enforceable ex post) even though an individual beneficiary might later find herself denied coverage for a necessary medical procedure.

107. See, e.g., Clark C. Havighurst, Altering the Applicable Standard of Care, LAW \& CONTEMP. PROBS., Spring 1986, at 265, 271-73 (suggesting examples of contractual language that would directly alter standard of care).

108. This would bring medical practice guidelines into malpractice disputes in a much different way than is usually suggested. Several commentators have argued that both plaintiffs and defendants in a malpractice suit should be allowed to introduce practice protocols into evidence as a means of establishing the applicable standard of care. Both sides would present different sets of guidelines (perhaps drafted for different purposes) and argue over which set represented the true standard. See, e.g., Troyen A. Brennan, Practice Guidelines and Malpractice Litigation: Collision or Cohesion?, 16 J. HEALTH POL., POL'Y \& L. 
Although courts have been extremely hesitant to enforce similarly restrictive insurance contract language in the past, ${ }^{109}$ several of the reform proposals currently under consideration in Congress would encourage institutional shifts in insurance contracting that might alleviate some of the traditional concerns with this sort of bargaining. ${ }^{10}$ The three proposals with the greatest current political support-the Clinton Administration's plan and the alternatives proposed by the Bipartisan Group on Health Reform and the Senate Republican Task Force on Health Care-all encourage the aggregation of individual consumers into insurance-purchasing cooperatives that would have real bargaining power vis-à-vis health care payors, and all would require these cooperatives to present their members with a varied menu of insuranceplan options as well as detailed health and welfare information on each plan offered. ${ }^{111}$ Depending on how far these changes went, a court might be persuaded that the usual factors counseling an override of restrictive contract language-consumer deficits in bargaining power, choice, and information-were no longer an obstacle to deference to the contract. In any event, an explicit statement from Congress that the standard of care was a legitimate topic for consumer bargaining would suffice; however, it would probably be unwise to force the matter along unless the institutional structure of the insurance market had changed sufficiently.

\section{Step Two: Determining Causal Responsibility and Apportioning Liability}

This discussion so far has considered how to define the standard of care so that we may determine the existence of medical negligence. Once collective medical negligence has been established-that is, once our court has determined that the treatment the patient received would not have met the required standard of care if prescribed by a single decisionmaker - the inquiry shifts to issues of causation and responsibility. Now that it has found that the

67 (1991); Hall, supra note 91. Instead, I propose having the plan member and the payor agree on an applicable set of protocols before there has been a medical injury; the standard of care to be applied at trial would thereby not be in dispute. For a similar proposal for resolving coverage disputes, see Havighurst, supra note 106, at $1795-98$.

109. See, e.g., Havighurst, supra note 106 , at 1767-68 (detailing judicial resistance to insurance contract language intended to deny coverage for medical treatments of questionable efficacy).

110. For an articulate statement of those concerns, see Maxwell J. Mehlman, Fiduciary Contracting: Limitations on Bargaining Between Patients and Health Care Providers, 51 U. PITT. L. REV, 365 (1990), especially 370-73 (concern for patients' lack of bargaining power and choice) and 374-88 (concern for information asymmetries).

111. See, e.g., S. 1757, 103d Cong., 1st Sess. § 5005(c)(1) (1993) (Administration plan; ordering health alliances to provide detailed cost and quality information for each plan offered members); H.R. 3222, 103d Cong., 1st Sess. \& 1203 (1993) (Bipartisan Group on Health Reform's alternative plan; ordering health plan purchasing cooperatives to gather standardized information on all plans made available to consumers); S. 1770, 103d Cong., 1st Sess. $\$ 1405$ (1993) (Senate Republican Task Force's alternative plan; ordering states to provide employers and purchasing cooperatives with reports comparing costs, medical outcomes, and customer satisfaction for all qualified health plans in state). 
prescribed course of care was deficient, the court must determine who was responsible for that prescription.

As suggested earlier, what has been traditionally considered medical decisionmaking authority is now diffused among professional and lay entities. Some form of enterprise liability, involving a full or partial shift of liability onto the health plan under which care has been provided, is an appropriate response to this diffusion. The Clinton Administration, as noted above, briefly considered a strong form of enterprise liability that would totally immunize physicians from suit and leave payors as the sole targets of litigation. ${ }^{12}$ Other commentators have taken the idea further, suggesting that courts dispense with inquiries into fault entirely and instead hold health plans strictly liable for all medical injuries-negligent or not-suffered by their beneficiaries. ${ }^{113}$

These strong forms of enterprise liability are probably premature, however. Although health professionals have become increasingly integrated into managed-care networks and other institutional arrangements under the control of third-party payors, that integration is nowhere near complete. Enterprise liability always creates difficult questions of line-drawing in an organizationally diverse sector of the economy: a unitary managed-care system that employed a salaried staff of physicians and owned its own facilities would clearly constitute a single "enterprise" that could be held solely liable, but where would liability rest in the case of a solo practitioner with staff privileges at a public hospital who treated a patient covered by a free-choice, fee-forservice plan that contracted with an independent utilization review firm? The drafters of the Administration's enterprise liability proposal were forced to take account of the vast plurality of organizational forms that would remain in the health care economy even after their plan's massive push towards managed care; the resulting complexity of the exceptions to their enterprise liability proposal threatened to swamp the plan regardless of the political forces arrayed against it. ${ }^{114}$

Our court, then, should adopt a weaker form of extended liability, one that recognizes that health care financing and provision are still organized in a plurality of ways, even though the industry may be moving as a whole towards greater integration. Here again we go back to the hidden insights of the Wilson court. Once the finder of fact has determined that a given course of medical treatment, regardless of how it was negotiated, was below par, she should

112. See supra note 10 .

113. See Weiler et al., supra note 6, at 2357-58.

114. Physicians who provided treatment to patients under Medicare would not be subject to the enterprise liability proposal's practitioner immunity, nor would physicians who continued to see patients outside the context of a health-alliance-approved plan. Physicians who saw a mixture of Medicare, plan, and nonplan patients would still have to maintain redundant malpractice insurance coverage for their nonimmunized activities. See Crane, supra note 10 , at 30,34 . 
apply the jurisdiction's applicable test for assigning liability in cases of joint causation. Using the Wilson court's test, the finder of fact should hold each entity whose actions were a "substantial factor" in making the treatment decision jointly and severally liable for the adverse medical outcome. ${ }^{115}$ This more flexible inquiry can be better tailored to the relationship between actors in a particular lawsuit than can a policy of stringent enterprise liability.

It is difficult to define precisely what conduct by a payor would constitute a "substantial factor" sufficient to incur liability. Clearly, those cases in which the third-party payor directly substituted its own prescription of care for that of the treating physician on the basis of independent medical expertise are at the test's core. On the other hand, the outcome in cases involving challenges to the indirect "chilling" effects of a payor's cost-containment mechanisms on physician practice would be less certain. But the test's flexibility is a virtue, not a defect: we are looking for a standard sensitive enough to detect when payors have compromised the provider's sole exercise of medical authority but not so rigid or automatic as to make meaningful cost containment impossible.

\section{CONCLUSION: LESSONS FOR WHOM?}

The inquiry proposed in the last section is eclectic: it responds to the recognition of the institutional contingency of the standard of care and the diffusion of medical authority with analyses drawn from a wide range of legal doctrines and policy perspectives. A court could adopt some aspects of this solution on its own; others realistically require some sort of legislative action. The judiciary would find it extremely difficult to extend malpractice liability honestly to third-party payors unless Congress repealed ERISA's preemption of state law or created a federal cause of action against health plans that could withstand ERISA. Likewise, legislative action would be required to uproot the rigid statutory distinctions between payors and providers in those jurisdictions that still abide by the old doctrines against the corporate practice of medicine. And courts would continue to shy away from enforcing contractual variations of the standard of care without some sort of legislative action either aggregating individual consumers into powerful and informed purchasing cooperatives or simply ordering the courts to defer to contractual bargains.

Nor is it clear that the courts should adopt the various elements of this solution piecemeal, fudging on the standard of care where possible, or extending malpractice liability sub rosa in the guise of policing an insurer's procedural obligations. The pieces of the solution form an integrated whole. Extending liability to third-party payors without allowing the duty of care to

115. For this to work fairly, of course, a third-party payor sued by a plaintiff who has not brought a similar action against the treating physician (as was the case in Wickline, Wilson, and Corcoran) must be allowed to implead the practitioner as an actor potentially responsible for the ultimate prescription of treatment. The plaintiff cannot determine the assignment of liability through her choice of defendants. 
vary sacrifices meaningful cost containment, while eroding the unitary standard of care without extending liability destroys payors' and physicians' accountability to patients by denying them compensation for their injuries. Similarly, moving to a "substantial factor" test of causation without sharpening the inquiry into medical negligence expands liability where there has been no wrongdoing; tightening the test of medical negligence without a structured analysis of causation leaves deficient decisionmaking uncorrected. The incremental and retrospective nature of case-specific adjudication may not be suited to work the fundamental doctrinal shifts needed in this fast-changing area. Adversarial litigation over an individual beneficiary's medical injuries is a particularly poor context in which to articulate rules of general applicability that should approximate what the broader pool of subscribers might want for itself at the point of joining a health plan. ${ }^{116}$

These concerns about the relative competence of the judiciary and the legislature aside, we would certainly expect some form of a solution to come from outside the courts. Because the standard of care in medical malpractice law is based on customary behavior, one might have thought it would evolve to reflect recent changes in practice styles. But the standard of care has proved remarkably resistant to change. Its conceptions of medical decisionmaking and medical authority run far too deep to be easily abandoned in the context of a particular malpractice dispute. Policymakers may be able to take advantage of the current political consensus to clear the field and start anew; right now, however, their inattention to the connections between cost containment and medical malpractice law risks making the clash between the economic imperatives of the new practice culture and the legal obligations of the old one far worse than it has ever been before.

116. Cf. Hall \& Anderson, supra note 62 , at 1679-81. 
